University of Nebraska - Lincoln

DigitalCommons@University of Nebraska - Lincoln

1989

\title{
THE STYLE OF LATE CENOZOIC DEFORMATION AT THE EASTERN FRONT OF THE CALIFORNIA COAST RANGES
}

Carl M. Wentworth

U.S. Geological Survey

Mark D. Zoback

Stanford University, zoback@stanford.edu

Follow this and additional works at: https://digitalcommons.unl.edu/usgsstaffpub

Part of the Earth Sciences Commons

Wentworth, Carl M. and Zoback, Mark D., "THE STYLE OF LATE CENOZOIC DEFORMATION AT THE EASTERN FRONT OF THE CALIFORNIA COAST RANGES" (1989). USGS Staff -- Published Research. 471. https://digitalcommons.unl.edu/usgsstaffpub/471

This Article is brought to you for free and open access by the US Geological Survey at DigitalCommons@University of Nebraska - Lincoln. It has been accepted for inclusion in USGS Staff -- Published Research by an authorized administrator of DigitalCommons@University of Nebraska - Lincoln. 
TECTONICS, VOL. 8, NO. 2, PAGES 237-246, APRIL 1989

THE STYLE OF LATE CENOZOIC DEFORMATION AT THE EASTERN FRONT OF THE CALIFORNIA COAST RANGES

Carl M. Wentworth

U.S. Geological Survey, Menlo Park, Califomia

Mark D. Zoback

Department of Geophysics, Stanford

University, Stanford, California
Abstract. The 1983 Coalinga earthquake occurred at the eastern boundary of the California Coast Ranges in response to northeast directed thrusting. Such movements over the past $2 \mathrm{Ma}$ have produced Coalinga anticline by folding above the blind eastem tip of the Coalinga thrust zone. The $600-\mathrm{km}$ length of the Coast Ranges boundary shares a common structural setting that involves westward uptum of Cenozoic and Cretaceous strata at the eastem front of the Coast Ranges and a major, southwest facing step in the basement surface beneath the western Great Valley. Like Coalinga anticline, Pliocene and Quaternary folding and faulting along the rest of the boundary also result from northeast-southwest compression acting nearly perpendicular to the strike of the San Andreas fault. We suggest that much of this deformation is related to active thrusts beneath the eastern Coast Ranges. The step in the basement surface beneath the Great Valley seems to have controlled the distribution of this deformation and the shape of the Coast Ranges boundary.

\section{INTRODUCTION}

The magnitude 6.7 earthquake that occurred beneath Coalinga anticline on May 2, 1983, has aroused new interest in structure along the east front of the Coast Ranges in central Califomia (Figure 1). This feature, here termed the Coast Ranges boundary, is a prominent topographic and structural boundary $600 \mathrm{~km}$ long that separates deformed rocks of the Coast Ranges from relatively undeformed rocks to the east beneath the Great Valley.

The Coalinga earthquake stimulated a variety of geological, geophysical, and seismological studies (Stein and King [1984], various papers cited by Rymer and Ellsworth [1985, 1989], and Namson and Davis, [1988]). Of particular interest is the

Copyright 1989

by the American Geophysical Union.

Paper number 88TC03969. $0278-7407 / 89 / 88 \mathrm{TC}-03969 \$ 10.00$ compressional focal mechanism determined for the Coalinga main shock [Eaton et al., 1983; Eaton, 1989], which represents thrust or reverse faulting directed perpendicular to the Coast Ranges boundary (Figures 1-4). We have examined the origin of the earthquake in the context of a broader study of the Coast Ranges boundary that is founded on a series of reflection profiles across the boundary at different latitudes [Wentworth et al., 1984, 1987; Zoback and Wentworth, 1986]. We present here a tectonic interpretation of the Coalinga earthquake that is founded on seismic reflection profiles in the epicentral region, but that integrates much of this other work as well.

We then examine the broader implications of our Coalinga interpretation. Similarities in structural relations and current stress orientation between the Coalinga area and the rest of the Coast Ranges boundary imply that the entire boundary is undergoing active thrusting and folding. As discussed by Page [1981], Zoback et al. [1987], and Mount and Suppe [1987], the orientation of this compression and shortening perpendicular to the San Andreas fault is incompatible with deformation in a wrench tectonic system [Moody and Hill, 1956; Harding, 1976].

The two seismic reflection profiles used in our interpretation of deep structure in the Coalinga area cross Coalinga anticline obliquely just to the north and south of the main shock epicenter (Figure 2). They were collected by Western Geophysical Company (6 s, 24 fold, VIBROSEIS) and later recorrelated to $12 \mathrm{~s}$ and reprocessed for the U.S. Geological Survey. The most useful reflection profile (SJ-19), which crosses the anticline $7 \mathrm{~km}$ southeast of the main shock epicenter (Figure 2), contains excellent detail to about $5 \mathrm{~s}$ (Figure 3). A second profile north of the epicenter (SJ-3), part of which is illustrated by Namson and Davis [1988, Figure 7], contains relatively few reflections below the base of the Cenozoic section, but does help corroborate continuity of structure beneath the length of the anticline. A 1977 COCORP line (Consortium for Continental Reflection Profiling) that crosses the southern tip of the anticline (Figure 2) is similar to profile SJ-19 but lacks its clarity and detail beneath the anticline. 


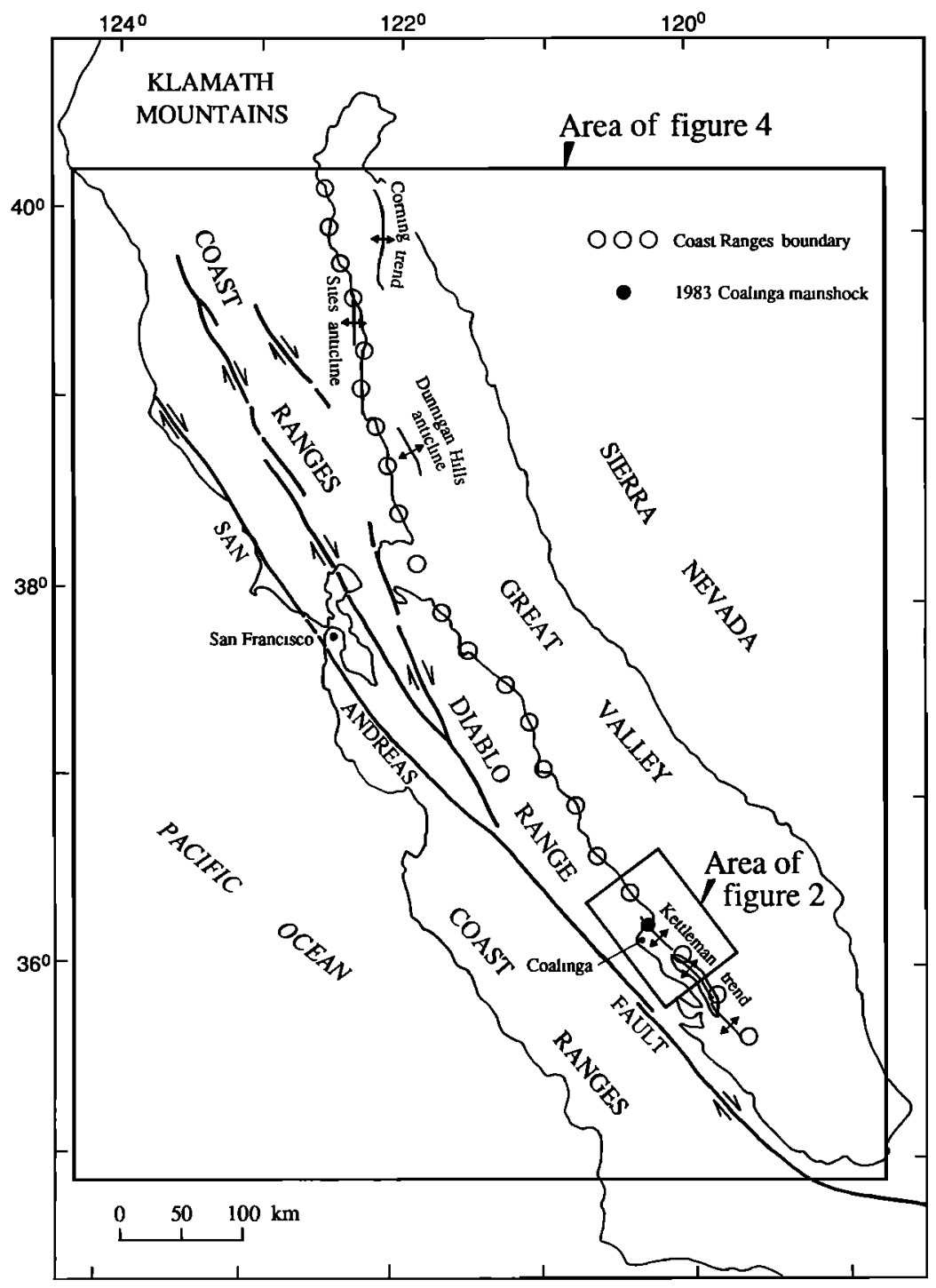

Fig. 1. Index map of central California showing major strike-slip faults and the Coast Ranges boundary between the Coast Ranges and the Great Valley.

\section{COAST RANGES BOUNDARY}

The Coast Ranges boundary (Figure 1) separates uplifted and strongly deformed rocks of the Coast Ranges on the west from depressed and relatively undeformed strata beneath the Great Valley on the east. These undeformed strata overlie west tilted crystalline basement that, in its exposed eastern part, consists of plutonic and metamorphic rocks of the western Sierra Nevada. The deepest exposed rock in the eastern Coast Ranges, in contrast, consists of the accreted Franciscan assemblage. Beneath the western Great Valley, 1-4 km of Upper Cretaceous sandstones and shales of the Great Valley sequence overlie crystalline basement. At the Coast Ranges boundary, these strata turn upward and thicken abruptly westward to the typically 8-15 km of Jurassic and Cretaceous section that are exposed along the eastern edge of the Coast Ranges. This thick section is coeval with the Franciscan assemblage, which it structurally overlies.

Wentworth et al. [1984] have used seismic reflection and refraction evidence at Coalinga and elsewhere to propose that the basement relations concealed beneath the Great Valley sequence along the Coast Ranges boundary involve a tectonic wedge of Franciscan rock that has been thrust eastward onto the continental margin. Principal emplacement of this obducted Franciscan wedge was probably completed by early Tertiary time, for the Franciscan assemblage was then unroofed and providing sediment to nearby basins [Dickinson, 1966; Berkland, 1973; Bartow et al., 1985] and vertical load was being applied to the crust west of the San Joaquin Valley [Rentschler and Bloch, 1988]. Folding within the Coast Ranges and at their eastern margin involves strata as young as Pliocene and Quatemary, however, and regional uplift of the 


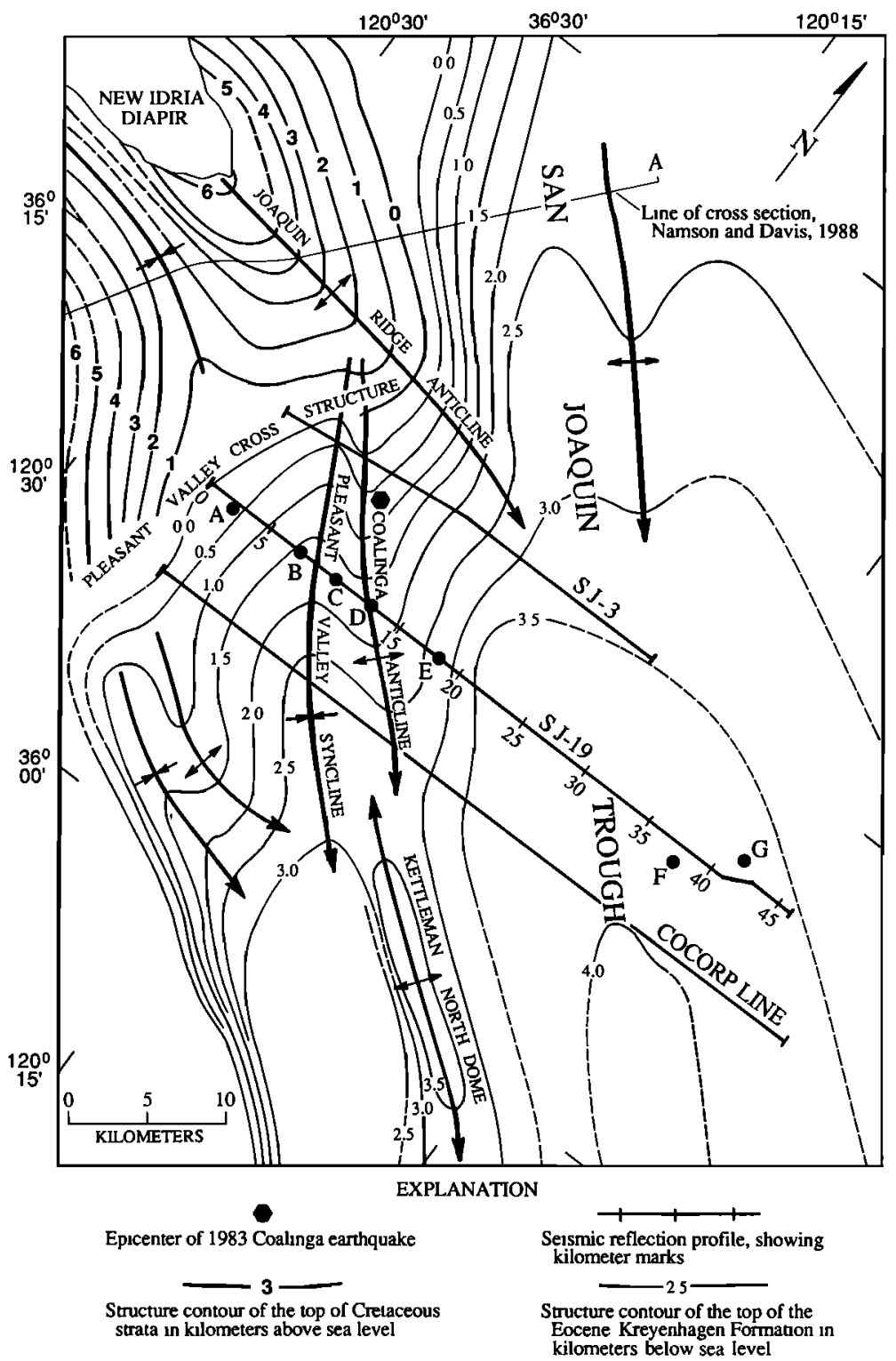

Fig. 2. Structural contour map showing Coalinga anticline and nearby folds, lines of reflection profiles, and well control along SJ-19 (lettered dots). Modified from Zigler et al. [1986].

present Coast Ranges is judged to be of similar age [Christensen, 1965; Page, 1981].

\section{COALINGA ANTICLINE AND THRUSTS}

The Coalinga earthquake occurred at the Coast Ranges boundary beneath Coalinga anticline, which is a young fold that plunges southeastward off the south flank of Joaquin Ridge anticline (Figure 2) and involves strata as young as the Pleistocene part of the Tulare Formation [Bartow, 1989] (Figure 3).

We distinguish between Joaquin Ridge anticline and Coalinga anticline (Figure 2) because they are separate folds with different histories. Most workers have considered them to be continuous [e.g., Amold and Anderson, 1910; Namson and Davis, 1988], although it was recognized 50 years ago that Coalinga anticline is a much younger fold Reed and Hollister, 1936, p. 67]. Joaquin Ridge anticline strikes west-northwest and has more than $4 \mathrm{~km}$ of structural relief, part of which predates the Miocene and Pliocene Etchegoin Formation [Dibblee, 1971; Casey and Dickinson, 1976; Harding, 1976; Wentworth and Zoback, 1989]. Coalinga anticline, in contrast, strikes northwest and has a structural relief of only $11 / 2 \mathrm{~km}$ that has developed largely in the past $2 \mathrm{Ma}$ (Figure 3, Bartow [1989], and Wentworth and Zoback [1989]).

The northwest termination of Coalinga anticline on the 
Coalinga Anticline
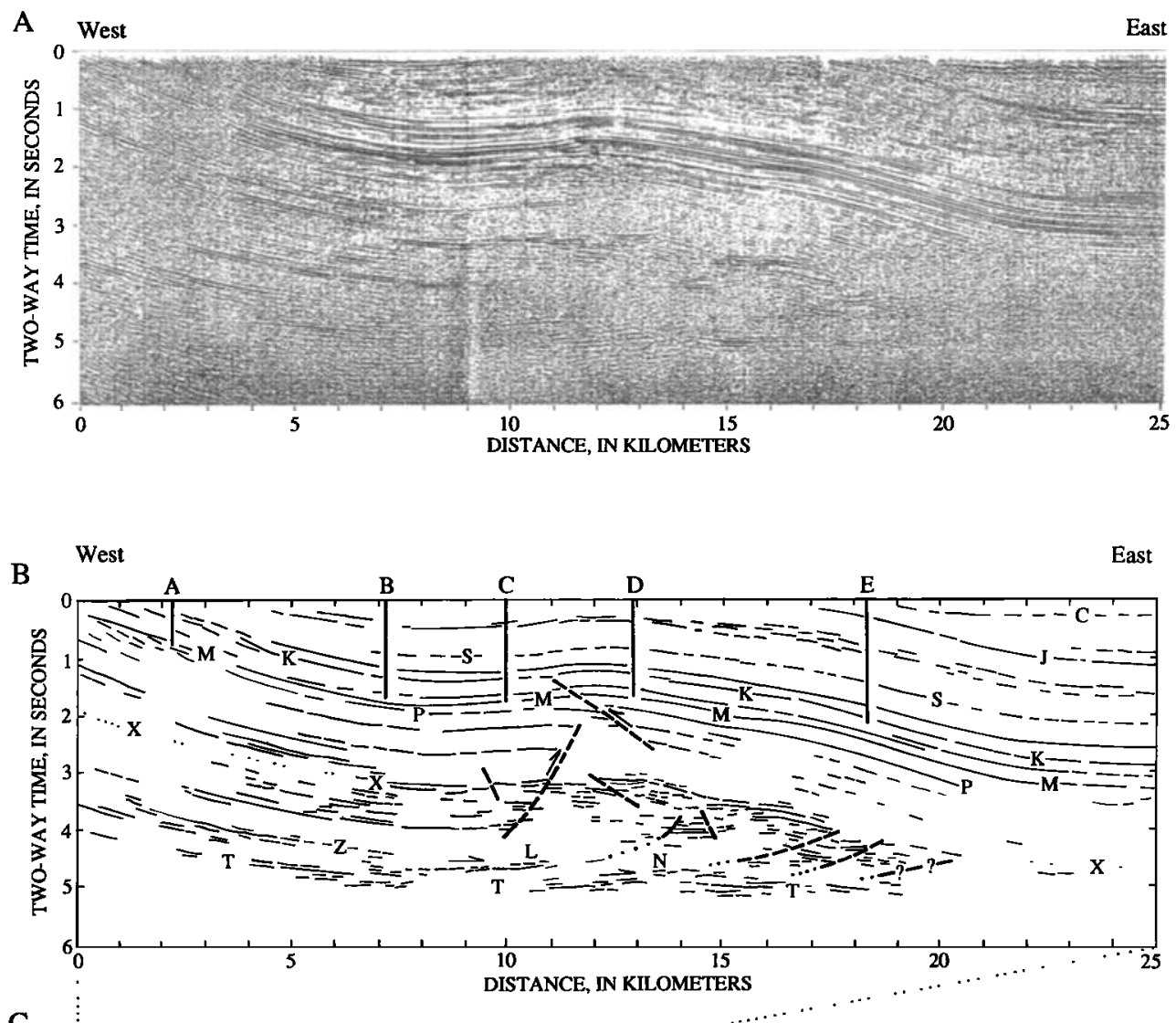

C

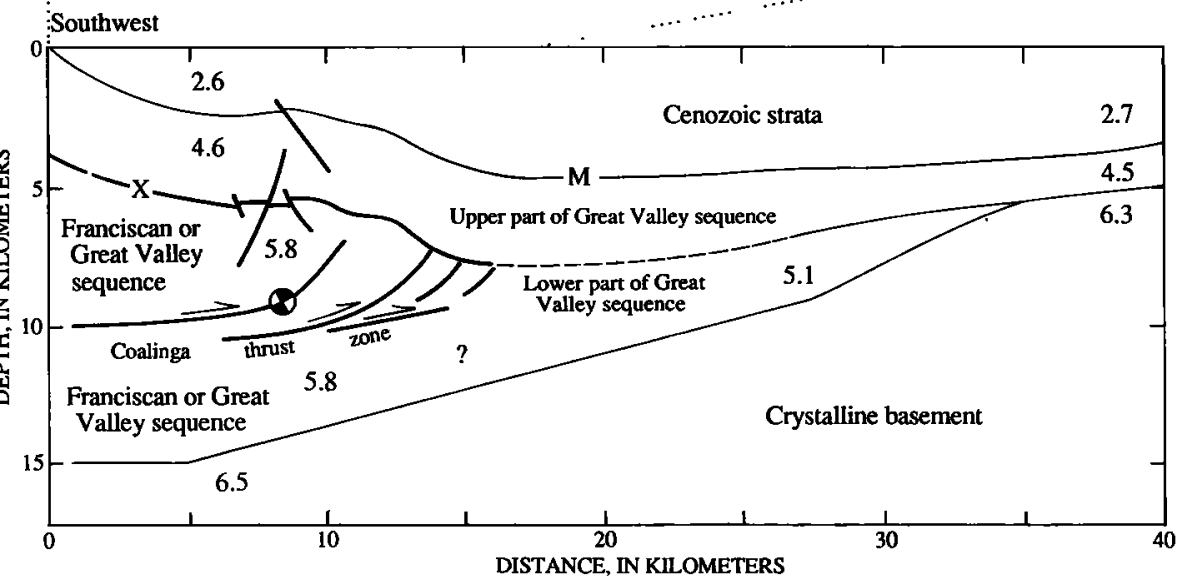

Fig. 3. Structure across Coalinga anticline. (a) Migrated reflection record of part of profile SJ-19. (b) Line drawing of Figure 3a. Stratigraphy from Bartow [1988]. Marked horizons: C, stratigraphic equivalent of Friant Pumice member of Turlock Lake Formation; J, top of San Joaquin Formation; S, top of Santa Margarita Formation, K, top of Kreyenhagen Formation; M, top of Moreno Formation and approximate top of Cretaceous strata. Other letters explained in text. Wells: A, Standard 302; B, Rheem Standard 28; C, Zwang 2-14; D, Union (R.S. Lyttle) USL68; E, Union Helm, Sumpf and Sumpf, Pleasant Valley 8-14. (c) Cross section projected to a northeast trending line normal to Coalinga anticline at its intersection with profile SJ-19. Seismic velocities, in kilometers per second, generalized from Wentworth and Zoback [1988] and Walter [1988]. Main shock focal mechanism of Eaton et al. [1983] projected and fitted to this cross section. 
south flank of Joaquin Ridge anticline and other aligned structural terminations to the south lead us to identify a diffuse feature, the northnortheast trending Pleasant Valley cross structure. We infer this feature to be a major tear fault in the subsurface across which the principal Diablo Range uplift steps to the right about $30 \mathrm{~km}$ (Figures 1 and 2). A few strike-slip events in the Coalinga aftershock sequence reinforce the existence of the Pleasant Valley cross structure: these earthquakes occurred along the cross structure at depths of 10 or more kilometers with their right-lateral focal planes oriented parallel to the cross structure [Eaton, 1989].

Coalinga anticline is clearly defined in the subsurface by numerous oil wells [Zigler et al., 1986] and the seismic reflection profiles (Figures 2 and 3). The crest and eastern flank of the anticline are separated by a distinct flattening of the strata (Figure 3, km 15) that divides the fold into two distinct steps (Figures 2 and 3). This fold configuration extends to a depth of several kilometers through the Cenozoic section and another $3 \mathrm{~km}$ of Cretaceous strata that form the upper part of the Great Valley sequence (Figure 3). This latter section is identified by correlation with wells to the east and outcrop to the west.

The rocks that underlie this upper part of the Great Valley sequence beneath the anticline are not penetrated by wells. Refraction profiling across the anticline [Walter, 1989] encounters basement rock of high seismic velocity $(6.5 \mathrm{~km} / \mathrm{s})$ at a depth of $15 \mathrm{~km}$ west of the anticline (Figure $3 \mathrm{c}$ ). This basement surface shallows to the east and is directly overlain by the upper part of the Great Valley sequence east of $\mathrm{km} 35$ on Figure $3 \mathrm{c}$. Beneath the anticline, the rock between the upper part of the Great Valley sequence and the basement surface is about $10 \mathrm{~km}$ thick and has a seismic velocity of about $5.8 \mathrm{~km} / \mathrm{s}$; farther east, it is thinner and has a velocity of about $5.1 \mathrm{~km} / \mathrm{s}$ (Figure $3 \mathrm{c}$ ).

Coalinga anticline is rooted within the upper half of the 10 $\mathrm{km}$-thick interval of 5.8-km/s rock. The top of this interval (horizon $\mathrm{X}$ ) is folded and faulted as part of the overlying Coalinga anticline, but the prominent reflections labeled $T$ (at about $5 \mathrm{~s}$, Figures $3 \mathrm{a}$ and $3 \mathrm{~b}$ ) do not participate in that folding. The slight angular discordance of the reflections labeled $\mathrm{Z}$ relative to the underlying $T$ reflections suggest that $T$ represents a fault zone. Reflections $\mathrm{L}$ and $\mathrm{N}$ splay upward from the $\mathrm{T}$ zone toward aligned terminations of reflections under the east limbs of the crest and east flank of the fold.

We interpret these relations together to indicate eastward thrusting along the $\mathrm{T}$ zone that splayed upward along reverse faults and then dispersed by folding to form Coalinga anticline. Similar but less distinct relations are present in profile SJ-3, which reinforces the conclusion that the faults and the anticline are causally related. The thrusts, which we name the Coalinga thrust zone, thus involve northeast directed movement perpendicular to the fold axis.

This interpretation contrasts with the fault-bend-fold interpretation of Namson and Davis [1988], which was founded on surface geology and drill holes across Joaquin Ridge anticline (Figure 2) and interpretation of reflection profile SJ-3 [Narnson and Davis, 1988, Figure 7]. Our own study of profile SJ-3 finds relations in the critical area beneath the east limb of Coalinga anticline to be ambiguous. The clarity of relations on profile SJ-19 (Figure 3) is more than sufficient, however, to deny the possibility of downward termination of strata in the east limb of Coalinga anticline against the footwall flat portion of a ramp flat thrust [Namson and Davis, 1988, Figures 6 and 7]. Our interpretation of profile SJ-19 also differs from that of Fielding et al. [1984], which was founded on the nearby COCORP profile.

\section{THE 1983 COALINGA EARTHQUAKE}

The main shock of the Coalinga earthquake sequence occurred at a depth of about $10 \mathrm{~km}$ beneath Coalinga anticline [Eaton et al., 1983; Eaton, 1989], which places it in the Coalinga thrust zone (Figure 3c). One focal plane of the main shock mechanism strikes $\mathrm{N} 53^{\circ} \mathrm{W}$, essentially parallel to the anticlinal axis, and dips $23^{\circ}$ to the southwest [Eaton, 1989]. This focal plane represents northeast directed thrusting that is similar to, but slightly steeper than, that of the Coalinga thrust zone. Coseismic surface deformation documented by Stein [1985] involved growth of the crest of the fold.

We thus conclude that the Coalinga main shock resulted from a northeast directed thrust event in the Coalinga thrust zone that splayed upward beneath the crest of the fold. The hypocenter appears to be located in the curved junction between the thrust ( $T$ ) and reverse splay (Figures $3 b$ and $3 c$ ), thus accounting for the dip of the thrust focal plane.

Aftershocks of the Coalinga main shock defined a complex pattem beneath Coalinga anticline and adjacent areas [Eaton, 1989; Eberhart-Phillips and Reasenberg, 1989]. A number of aftershocks occurred approximately along the Coalinga thrust zone and the updip reverse splay beneath the fold crest that involved subhorizontal compression similar to that of the main shock. Others imply the presence of thrusting farther northwest. Although we conclude from the uplift pattern that main shock rupture terminated at the Pleasant Valley cross structure, numerous thrust aftershocks near the depth of the Coalinga thrust zone extended another $10 \mathrm{~km}$ to the northwest beneath Joaquin Ridge anticline.

We have tested the ability of the Coalinga thrust and reverse splay to produce the observed surface uplift using dislocation modeling [Wentworth and Zoback, 1989]. The thrust and reverse faults were represented by gently and steeply dipping planes striking parallel to the anticline and joining near the main shock hypocenter. A fault length of $16 \mathrm{~km}$ was defined between the Pleasant Valley cross structure on the northwest and the southeast end of uplift and aftershocks. We find a reasonable fit to the observed surface uplift for thrust and reverse planes with widths (dip extent) of 4 and $7 \mathrm{~km}$ and dip slips of 2 and $1.2 \mathrm{~m}$, respectively. This dislocation model is similar to that of Stein [1985, Figure 3d] and yields an aggregate seismic moment for the bilateral rupture of about $8.6 \times 10^{25} \mathrm{dyn} . \mathrm{cm}$. This result is in fair agreement with those of Hartzell and Heaton [1983] and Kanamori [1983] determined from seismic radiation

\section{REGIONAL SETTING OF COALINGA STRUCTURES}

Coalinga anticline and the underlying Coalinga thrusts occur at the Coast Ranges boundary where the top of deep crystalline basement begins to shallow eastward (Figure 3c). The basement surface rises at nearly $20^{\circ}$ from a depth of about $15 \mathrm{~km}$ west of the anticline to about $6 \mathrm{~km}$ east of it $(\mathrm{km} \mathrm{35}$, Figure 3c), where the surface abruptly flattens to a more gradual eastward rise beneath the San Joaquin Valley (Figures $3 c$ and 4). This step in the basement surface is defined principally by the seismic refraction model of Walter [1989], but is corroborated by magnetic and gravity interpretation [Griscom and Jachens, 1989] and by coincidence of the refraction basement surface with a strong reflection at $3.8 \mathrm{~s}(5.6 \mathrm{~km})$ on profile SJ-19 at km 43 (Figures 2 and 3).

The identity of the thick interval of rock between crystalline basement and the base of the upper part of the Great Valley sequence is difficult to determine. Wells in the San Joaquin Valley $20 \mathrm{~km}$ east of the profile encounter about 


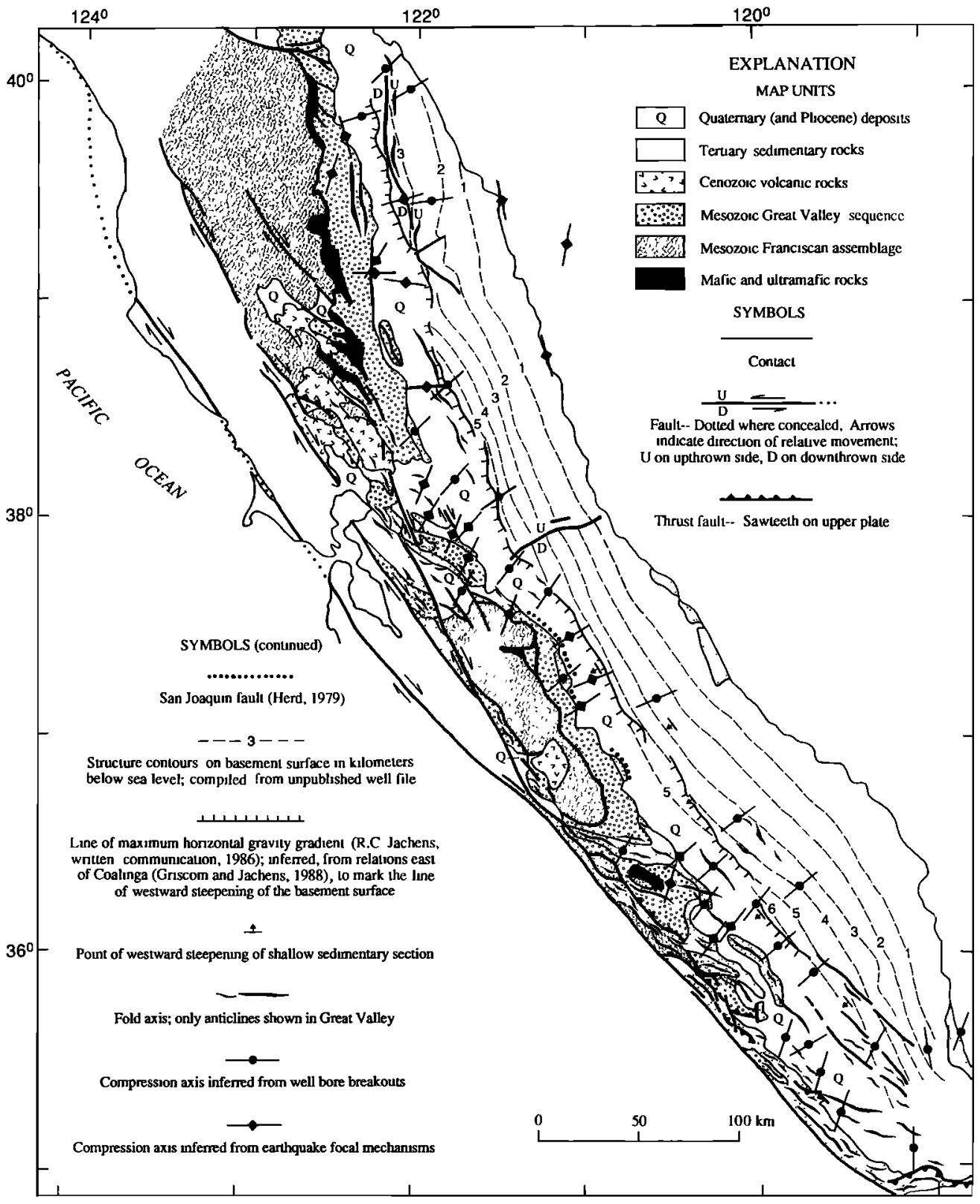

Fig. 4. Compression directions and fold axes associated with the Coast Ranges boundary in the context of generalized geology in the Coast Ranges and the basement surface beneath the Great Valley. Geology modified from Jennings [1977] principally using the works by M. C. Blake, Jr. (written communication, 1987), Harwood and Helley [1987], Pampeyan et al. [1981], Wentworth and Zoback [1988], and Zigler et al. [1986]. Compression directions generalized from compilation of Zoback et al. [1987], Mount and Suppe [1987], and Wong et al. [1988]. See text for sources of points of westward steepening of shallow section in the Great Valley.

$1 \mathrm{~km}$ of Great Valley sequence that unconformably overlies crystalline basement, whereas in the mountains to the west about $8 \mathrm{~km}$ of Great Valley sequence are exposed that structurally overlie the Franciscan assemblage.

Rock east of the anticline in the interval between basement and the upper part of the Great Valley sequence is probably lower Great Valley sequence, as it yields poorly defined, west dipping reflections (not illustrated in Figure 3 ) and has a refraction velocity $(5.0-5.2 \mathrm{~km} / \mathrm{s})$ that is only slightly higher than the $4.8 \mathrm{~km} / \mathrm{s}$ observed in Great Valley sequence at shallower depth elsewhere [Walter and Mooney, 1982]. Below and west of the anticline, in contrast, the seismic velocity in this interval is higher and has values $(5.7-6.1 \mathrm{~km} / \mathrm{s})$ that are typical of Franciscan rock elsewhere in the Diablo Range [Stewart and 
Peselnick, 1978; Walter and Mooney, 1982]. It is the presence of such a body of relatively high-velocity rock separating Great Valley sequence above from an essentially continuous basement surface below, both here and elsewhere, that led to the proposal of a tectonic wedge of Franciscan assemblage at the Coast Ranges boundary [Wentworth et al., 1984].

The whole $10-\mathrm{km}$ thickness of $5.8-\mathrm{km} / \mathrm{s}$ rock beneath and west of Coalinga anticline cannot be a tectonically emplaced wedge of Franciscan rock, however, because emplacement of such a thickness of rock would have raised the overlying section appreciably more than is now evident (Figure 3c). We conclude that the interval is half lower Great Valley sequence and half Franciscan assemblage [Wentworth and Zoback, 1989]. If the upper part of the interval is Great Valley sequence and the lower part Franciscan assemblage, then the continuous, layered reflections in the X-T interval (Figure 3) are well accounted for, although the seismic velocity is anomalously high for Great Valley sequence at that depth. In this case the Coalinga thrusts follow the Coast Range thrust at the roof of the Franciscan wedge (Figure 3c). Conversely, if the lower half of this interval is Great Valley sequence and the upper half Franciscan assemblage, the deep burial of the Great Valley sequence helps account for the high seismic velocity. In this case the Coalinga thrusts represent a continuation of eastward thrust movement along the base of the Franciscan wedge. Resolution of this uncertainty is not essential to the present discussion.

Although uplift of the Coast Ranges west of Pleasant Valley begail by early Tertiary time, as indicated by angular unconformity at the base of the Cenozoic section (km 1 on Figure 3b), Coalinga anticline is much younger. Thinning across the crest of the fold began only with upper Pliocene strata of the San Joaquin Formation [Bartow, 1989] and is prominent in SJ-19 only above the top of that formation, which is about 2 Ma old [Sama-Wojcicki et al., 1985]. Continued folding involved horizon $\mathrm{C}$, which is the stratigraphic equivalent of the 0.6 Ma Friant Pumice Member of the Turlock Lake Formation. This equivalence (J. A. Bartow, oral communication, 1984) is based on correlation between geophysical logs of oil wells and depth to the Corcoran Clay member in shallow wells [e.g., Page, 1986].

Deformation associated with Coalinga anticline thus began in late Pliocene time, when we infer that the Franciscan wedge advanced beneath Pleasant Valley and raised the overlying strata. Movement then proceeded along the Coalinga thrust zone and formed the balance of the fold. The geometry of the fold suggests that several kilometers of thrust offset were required to form it. Over the 2 million years of fold growth, this represents shortening of about $4 \mathrm{~km}$, which is several percent of the rate of lateral movement along the San Andreas fault.

\section{SIMILARITIES ALONG THE COAST RANGES BOUNDARY}

The principal elements of the regional setting at Coalinga are common to the whole length of the Coast Ranges boundary. Most evident is the parallelism along the boundary between the abrupt westward uptum of Cenozoic and Cretaceous strata and the step in the basement surface to the east beneath the Great Valley (Figure 4). That basement surface dips gently westward beneath the eastern two thirds of the valley (to the hachured line on Figure 4) before stepping down more steeply toward the leading edge of the Coast Ranges. There, it flattens and continues beneath the edge of the Coast Ranges (see Figure 3c). A third, less certain, parallel feature is the buried tip of the Franciscan wedge, which is inferred to have been thrust eastward across this basement surface approximately to the Coast Ranges boundary [Wentworth et al., 1984].

The Coast Ranges boundary is prominently marked by westward upturning of strata as young as Pliocene and Pleistocene, by uplift of the Coast Ranges to the west, and by parallel folding along and east of the boundary (Figure 4). The orientation of these folds and the shape of the Coast Ranges boundary itself closely fit the shape of the line of westward steepening of the basement surface, which typically lies 15 to $20 \mathrm{~km}$ east of the boundary.

In the southern Great Valley, an apparent line of slight but distinct, westward steepening of the shallow sedimentary section above that line of basement steepening seems to mark another feature parallel to the Coast Ranges boundary. Four of five points of control nearly coincide in plan view with the inferred line of basement steepening (Figure 4). This shallow steepening is evident on seismic refection lines at latitudes 35.8, 36.2, and 37.3 [Wentworth et al., 1983, Figure 3, km 68; Wentworth and Zoback, 1988, Plate 1a, km 38; Wentworth et al., 1987, Figure 2, km 47] and on detailed cross sections at latitudes 36.7 and 37.1 [Lettis, 1982]. These detailed cross sections show this deformation to have continued at least into early Riverbank time $(300-450 \mathrm{Ka}$; Lettis [1982, 1988]).

Many of the folds along and east of the Coast Ranges boundary are young, particularly southeast of Coalinga along the Kettleman Hills anticlinal trend and nearby, but also farther north [see Jennings, 1977]. The most prominent young fold along the northern part of the boundary is Dunnigan Hills anticline (Figures 1 and 4), where upper Quaternary strata are involved in the folding [Harwood and Helley, 1987]. In contrast to the Kettleman trend, Sites anticline, which similarly occurs at the Coast Range boundary but near its northern end, is unconformably overlain by Pliocene Tehama Formation (3.4 Ma) and shows no Quaternary folding [Helley and Harwood, 1985]. To the east of it, however, folds along the Corning anticlinal trend (Figures 1 and 4) do involve upper Quaternary strata and are associated with steep faults that show reverse offset of the basement surface [Harwood and Helley, 1987; Harwood, 1984, Figure 5]. Similarly, young folds in the southern Great Valley east of the Kettleman trend are probably also related to reverse faults in basement [Wentworth et al., 1983; Wentworth and Zoback, 1989].

At the eastem front of the central Diablo Range, the Coast Ranges boundary is distinguished by the early Quaternary San Joaquin fault (Figure 4), which exhibits down-to-the-east offset locally greater than 140-220 m [Herd, 1979; Lettis, 1982]. Although considered a normal fault by Herd [1979], this fault probably also results from compressive deformation across the Coast Ranges boundary and is now considered likely to be a thrust or reverse fault by Lettis [1988].

West of the southern part of the San Joaquin fault, Lettis [1982] has mapped numerous down-to-the-west reverse faults that document continuing eastward tilting of the Great Valley sequence in the eastem Diablo Range during Quaternary time.

The eastern margin of the uplifted Franciscan core of the northem Coast Ranges and central Diablo Range is also parallel to the Coast Ranges boundary (Figure 4). It lies 15 to $20 \mathrm{~km}$ west of the boundary and typically separates high, rugged topography in the Franciscan terrane from more subdued topography on Great Valley sequence. This contact has long been considered the surface trace of the Coast Range thrust. In most places, however, it actually consists of steep Cenozoic faults (Coast Range fault, Tesla-Ortigalita fault) that have undergone dip slip associated with range uplift and, in the 
Diablo Range, right-lateral strike slip as well [Raymond, 1973; Page, 1981; Anderson et al., 1982; Jayko and Blake, 1988, also oral communication, 1988]

\section{STATE OF STRESS ALONG THE COAST RANGES BOUNDARY}

The direction of maximum horizontal compression indicated by earthquake focal mechanisms and well bore breakouts along the length of the Coast Ranges boundary is consistently northeast-southwest (Figure 4). Mount and Suppe [1987] show that the mean orientation of fold axes in the Coalinga region is essentially perpendicular to the maximum horizontal compressive stress. In fact, this relation holds in detail along the whole length of the Coast Ranges boundary, both with the folds and with the line of basement steepening: where their orientation varies locally, so too does the compression direction (Figure 4).

The breakout stress orientations shown in Figure 4 were mostly obtained by Mount and Suppe [1987] from wells that range in depth from 0.2 to $4.6 \mathrm{~km}$ in sedimentary rock. The close agreement between these orientations and those deduced from the focal mechanisms of earthquakes at depths of about 3 to $12 \mathrm{~km}$ (Figure 4) shows that the sedimentary strata are folding in response to the same stress field that affects the seismogenic thickness of the crust [Zoback et al., 1987]. Thus a consistent relation between deep faulting and shallow folding, which we have documented at Coalinga, probably exists along much of the Coast Ranges boundary.

A surprising feature of the observed direction of maximum horizontal compression along the Coast Ranges boundary is that it is nearly perpendicular to the strike of the San Andreas fault, suggesting that the San Andreas is moving under very low shear stress [Zoback et al., 1987; Mount and Suppe, 1987]. This northeast directed compression probably began at about 3.6 Ma [Harbert and Cox, 1986], when a slight clockwise change in the direction of Pacific plate motion relative to North America introduced a small component of convergence across the San Andreas fault [Cox and Engebretson, 1985]. Zoback et al. [1987] argue that the high angle of maximum horizontal stress across the fault is actually caused by low shear strength along the fault.

\section{CONCLUSIONS}

Modern compression directions determined from earthquakes and well bore breakouts in the easternmost Coast Ranges and the Great Valley indicate that the entire length of the Coast Ranges boundary is undergoing compression and resultant shortening that is essentially perpendicular to that boundary. Although this compression probably derives from plate interactions at the San Andreas transform, its orientation nearly perpendicular to the transform is not compatible with conventional wrench tectonics.

A line of abrupt westward steepening of the basement surface beneath the Great Valley, inferred largely from geophysical data, lies about $20 \mathrm{~km}$ east of the Coast Ranges boundary. This line of steepening and the Coast Ranges boundary extend in closely parallel fashion for almost the whole $600-\mathrm{km}$ length of the Califomia Coast Ranges. Near coincidence with the apparent line of westward steepening in the shallow sedimentary section in the southern Great Valley implies that this break in basement slope has exerted control on late Quatemary deformation.

Folds at the Coast Ranges boundary and in the western Great Valley are oriented parallel to the local orientations of the boundary and the line of basement steepening and perpendicular to the local compression direction. Along the southern part of the boundary, the compression is producing a $100-\mathrm{km}$ long zone of anticlines located at the boundary. We have shown that the young folding at Coalinga anticline is the shallow expression of deeper thrusting. Structure there, at Kettleman South Dome [Wentworth et al., 1983], and at Lost Hills [Medwedeff and Suppe, 1986] all suggest that this whole anticlinal trend results from blind thrusting beneath the folds. Coalinga aftershocks indicate that thrusting extends beneath Joaquin Ridge anticline, and local folding at the boundary farther north may also result from deeper thrusting. Near the north end of the boundary, however, the prominent folding at Sites anticline seems to predate the current tectonic regime.

Young folding east of the Coast Ranges boundary is a product of the same compression. Where basement is deep this folding may also reflect underlying thrusts, but to the east where basement is shallower the folding probably overlies reverse faults.

Faulting, eastward tilting, and associated uplift of the eastem Coast Ranges may also be related to underlying thrusts moving under northeast-southwest compression.

We suggest that much of the young folding and faulting along the Coast Ranges boundary is the shallow expression of deeper thrusting that is driven by northeast-southwest compression. The detailed geometric association between this deformation and the line of abrupt westward steepening of basement implies fundamental control of that deformation by the step in the basement surface beneath the western Great Valley.

\section{REFERENCES}

Anderson, L. W., M. H. Anders, and D. A. Ostenaa, Late Quaternary faulting and seismic hazard potential, eastern Diablo Range, California, in Proceedings, Conference on Earthquake Hazards in the Eastern San Francisco Bay Area, Spec. Publ. 62, edited by E. W. Hart, S. E. Hirschfeld, and S. S. Shulz, pp. 197-206, California Division of Mines and Geology, Sacramento Calif., 1982.

Arnold, R., and R. Anderson, Geology and oil resources of the Coalinga District, U.S. Geol. Surv. Bull., 398, 1910.

Bartow, J.A., Cenozoic stratigraphy and geologic history of the Coalinga region, central Califomia, in The Coalinga, California, Earthquake of May 2, 1983, Prof. Pap. 1487, edited by M. J. Rymer, and W.L. Ellsworth, U.S. Geological Survey, Reston, Va., in press, 1989.

Bartow, J. A., W. R. Lettis, H. S. Sonneman, and J. R. Switzer, Jr., Geologic map of the east flank of the Diablo Range from Hospital Creek to Poverty Flat, San Joaquin, Stanislaus and Merced Counties, California, U.S. Geol. Surv. Misc. Invest. Ser., Map I-1656, 1985.

Berkland, J. O., Rice Valley outlier--New sequence of Cretaceous-Paleocene strata in northern Coast Ranges, California, Geol. Soc. Am. Bull., 84, 2389-2406, 1973.

Casey, T. A. L., and W. R. Dickinson, Sedimentary serpentinite of the Miocene Big Blue Formation near Cantua Creek, California, in The Neogene Symposium, edited by A. E. H. Fritsche, H. TerBest, Jr, and W. W. Wornardt, pp. 65-74, Society of Economic Paleontologists and Mineralogists, Pacific Section, Bakersfield, Calif., 1976.

Christensen, M. N., Late Cenozoic deformation in the central Coast Ranges of California, Geol. Soc. Am. Bull., 76, 1105-1124, 1965.

Cox, A., and D. Engebretsen, Change in motion of Pacific plate at 5 Myr BP, Nature, 313, (6002), 472-474, 1985.

Dibblee, T. W., Geologic maps of the Coalinga, Joaquin 
Rocks, New Idria, and Priest Valley 15 minute quadrangles, California, U.S. Geol. Surv. Open File Rep., 71-87, 1971.

Dickinson, W. R., Table Mountain serpentinite extrusion in California Coast Ranges, Geol. Soc. Am. Bull., 77, 451472, 1966.

Eaton, J. P., The earthquake and its aftershocks from May 2 through September 30, 1983, in The Coalinga, California. Earthquake of May 2, 1983, Prof. Pap., 1487, edited by M. J. Rymer and W. L. Ellsworth, U..S. Geological Survey, Reston, Va., in press, 1989.

Eaton, J., R. Cockerham, and F. Lester, Study of the May 2, 1983 Coalinga earthquake and its aftershocks, based on the USGS seismic network in northern California, in The 1983 Coalinga, California, Earthquakes. Spec. Publ. 66, edited by J. H. Bennett, J. H., and R. W. Sherburne, pp. 261274, California Division of Mines and Geology, Sacramento, Calif., 1983.

Eberhart-Phillips, D., and P. Reasenberg, Complex faulting structure inferred from local seismic observations of M 1.0 aftershocks, May 2-June 30, 1983, in The Coalinga, California, Earthquake of May 2, 1983, Prof. Pap. 1487, edited by M. J. Rymer and W. L. Ellsworth, U. S. Geological Survey, Reston, Va., in press, 1989.

Fielding, E., M. Barazangi, L. Brown, J. Oliver, and S. Kaufman, COCORP seismic profiles near Coalinga, Califomia: Subsurface structure of the western Great Valley, Geology, 12, 268-273, 1984.

Griscom, A., and R. C. Jachens, Tectonic implications of gravity and magnetic models along east-west seismic profiles across the Great Valley near Coalinga, in The Coalinga, California, Earthquake of May 2, 1983, Prof. Pap. 1487, edited by M. J. Rymer, and W. L. Ellsworth, U. S. Geological Survey, Reston, Va., in press, 1989.

Harbert, W., and A. Cox, Late Neogene motion of the Pacific plate (abstract), EOS Trans. AGU, 67, 1225, 1986.

Harding, T. P., Tectonic significance and hydrocarbon trapping consequences of sequential folding synchronous with San Andreas faulting, San Joaquin Valley, California, Am. Assoc. Pet. Geol. Bull., 60, 356-378, 1976.

Hartzell, S. H., and T. H. Heaton, Teleseismic mechanism of the May 2, 1983 Coalinga, California, Earthquake, in The 1983 Coalinga, California, Earthquake, Spec. Publ. 66, edited by J. H. Bennett and R. W. Sherbume, pp. 241-246, California Division of Mines and Geology, Sacramento, Calif., 1983.

Harwood, D. S., Evidence for late Cenozoic east-west compressive tectonism in the Sacramento Valley, California, in Tectonics and Sedimentation along the California Margin, vol. 38, edited by J. K. Crouch, and S. B. Bachman, pp. 87-100, Society of Economic Paleontologists and Mineralogists, Pacific Section, Bakersfield, Calif., 1984.

Harwood, D. S., and E. J. Helley, Late Cenozoic tectonism of the Sacramento Valley, California, U.S. Geol. Surv. Prof. Pap., 1359, 1987.

Helley, E. J., and D. S. Harwood, Geologic map of the late Cenozoic deposits of the Sacramento Valley and northern Sierran foothills, California, U.S. Geol. Surv. Misc. Field Stud., Map MF-1790, 1985.

Herd, D. G., Generalized geologic map of the San Joaquin fault zone, scale 1:750,000, in Summaries of Technical Reports, compiled by W. H. Seiders, U.S. Geol. Surv., Reston, Va., 1979.

Jayko, A. S., and M. C. Blake Jr., Deformation of the eastern Franciscan belt, northern California, J. Struct. Geol., in press, 1989.

Jennings, C. W., Geologic map of California, Geologic Data
Map 2, scale 1:750,000, Calif. Div. of Mines and Geol., Sacramento, Calif., 1977.

Kanamori, H., Mechanism of the 1983 Coalinga earthquake determined from long period surface waves, in The 1983 Coalinga, California, Earthquakes, Spec. Publ. 66, edited by J. H. Bennett and R. W. Sherburne, pp. 233-240, California Division of Mines and Geology, Sacramento, Calif., 1983.

Lettis, W. R., Late Cenozoic stratigraphy and structure of the western margin of the central San Joaquin Valley, California, U.S. Geol. Surv. Open File Rep., 82-526, 1982.

Lettis, W. R., Quaternary geology of the northem San Joaquin Valley, in Studies of the Geology of the San Joaquin Basin, vol. 60, edited by S. A. Graham and H. C. Olson, pp. 29-57, Society of Economic Paleontologists and Mineralogists, Pacific Section, Bakersfield, Calif., 1988.

Medwedeff, D. A., and J. Suppe, Growth fault-bend folding -Precise determination of kinematics, timing, and rates of folding and faulting from syntectonic sediments, Geol. Soc. Am. Abstr. Programs, 18, 692, 1986.

Moody, J. D., and M. J. Hill, Wrench-fault tectonics, Geol. Soc. Am. Bull., 1207-1246, 1956.

Mount, V. S., and J. Suppe, State of stress near the San Andreas fault: Implications for wrench tectonics, Geology, 15, 1143-1146, 1987.

Namson, J. S., and T. L. Davis, Seismically active fold and thrust belt in the San Joaquin Valley, central California, Geol. Soc, Am. Bull., 100, 257-273, 1989.

Page, B. M., The southern Coast Ranges, in The Geotectonic Development of California, edited by W. G. Enst, pp. 329-417, Prentice-Hall, Englewood Cliffs, N.J., 1981.

Page, R. W., Geology of the fresh ground-water basin of the Central Valley, California, with texture maps and sections, U.S. Geol. Surv. Spec. Pap., 1401-C, Plate 4, 1986.

Pampeyan, E. H., P. W. Harsh, and J. M. Coakley, Preliminary map showing recently active breaks along the Maacama fault zone between Hopland and Laytonville, Mendocino County, California, U.S. Geol. Surv. Misc. Field Stud., Map MF-1217, 1981.

Raymond, L. A., Tesla-Ortigalita fault, Coast Range thrust fault, and Franciscan metamorphism, northeastern Diablo Range, California, Geol. Soc. Am. Bull., 84, 3547-3562, 1973.

Reed, R. D., and J. S. Hollister, Structural Evolution of Southern California, 157 pp., American Association of Petroleum Geologists, Tulsa, Okla., 1936.

Rentschler, M. S., and R. B. Bloch, Flexural subsidence modeling of the Tertiary San Joaquin basin, California, in Studies of the Geology of the San Joaquin Basin, edited by S. A. Graham and H. C. Olson, vol. 60 , pp. $29-57$, Society of Economic Paleontologists and Mineralogists, Pacific Section, Bakersfield, Calif., 1988.

Rymer, M. L., and W. L. Ellsworth, (eds.), Mechanics of the May 2, 1983 Coalinga Earthquake, U.S. Geol. Surv. Open File Rep., 85-44, 438 pp., 1985.

Rymer, M. J., and W. L. Ellsworth, (eds.), The Coalinga, Califomia, earthquake of May 2, 1983, U.S. Geol. Surv. Prof. Pap., 1487, in press, 1989.

Sarna-Wojcicki, A. M., C. E. Meyer, H. R. Bowman, N. T. Hall, P. C. Russell, M. J. Woodward, and J. L. Slate, Correlation of the Rockland ash bed, a 400,000-year-old stratigraphic marker in northem Califomia and western Nevada, and implications for middle Pleistocene paleogeography of central Califomia, Quat. Res., N.Y., 23 , 236-257, 1985 . 
Stein, R. S., Evidence for surface folding and subsurface fault slip from geodetic elevation changes associated with the 1983 Coalinga, California, Earthquake, in Mechanics of the May 2, 1983 Coalinga Earthquake, Open File Rep., 85-44. edited by M. J. Rymer and W. L. Ellsworth, pp. 225-253, U.S. Geological Survey, Reston, Va., 1985.

Stein, R. S., and C. P. King, Seismic potential revealed by surface folding: 1983 Coalinga, California, earthquake, Science, 224, 869-872, 1984.

Stewart, R., and L. Peselnick, Systematic behavior of compressional velocity in Franciscan rocks at high pressure and temperature, J. Geophys. Res., 83, 831-839, 1978.

Walter, A. W., Upper-crustal velocity structure near Coalinga, as determined from seismic-refraction data, in The Coalinga, California, Earthquake of May 2, 1983, Prof. Pap., 1487, edited by M. J. Rymer, and W. L. Ellsworth, U.S. Geological Survey, Reston, Va., in press, 1989.

Walter, A. W., and W. D. Mooney, Crustal structure of the Diablo and Gabilan Ranges, central California, A reinterpretation of existing data, Bull. Seismol. Soc. Am., 72, $1567-1590,1982$.

Wentworth, C. M., and M. D. Zoback, Structure of the Coalinga region and thrust origin of the earthquake, in The Coalinga, California, Earthquake of May 2, 1983, Prof. Pap. 1487, edited by M. J. Rymer, and W. L. Ellsworth, U.S. Geological Survey, Reston, Va., in press, 1989.

Wentworth, C. M., A. W. Walter, J. A. Bartow, and M. D. Zoback, Evidence on the tectonic setting of the 1983 Coalinga earthquakes from deep reflection and refraction profiles across the southeastem end of Kettleman Hills, in The 1983 Coalinga, California, Earthquakes, Spec. Publ. 66, edited by J. H. Bennett and R. W. Sherburne, pp. 113126, California Division of Mines and Geology, Sacramento, Calif., 1983.

Wentworth, C. M., M. C. Blake, Jr., D. L. Jones, A. W. Walter, and M. D. Zoback, Tectonic wedging associated with emplacement of the Franciscan assemblage, Califomia Coast Ranges, in Franciscan Geology of Northern California, vol. 43, edited by M. C. Blake, Jr., pp. 163173, Society of Economic Paleontologists and Mineralogists, Pacific Section, Bakersfield, Calif., 1984.

Wentworth, C. M., M. D. Zoback, Andrew Griscom, R. O. Jachens, and W. D. Mooney, A transect across the Mesozoic accretionary margin of central California, Geophys. J. R. Astron. Soc., 89, 105-110, 1987.

Wong, I. G., R. W. Ely, and A. C. Kollman, Contemporary seismicity and tectonics of the northern and central Coast Ranges-Sierran block boundary zone, California, $J$. Geophys. Res., 93, 7813-7833, 1988.

Zigler, J. L., C. M. Wentworth, and J. A. Bartow, Structure contour map of the tops of the Kreyenhagen Formation and Cretaceous strata in the Coalinga area, Fresno and Kings Counties, California, scale 1:100,000, U.S. Geol. Surv. Misc. Field Stud., Map MF-1843, 1986.

Zoback, M. D., and C. M. Wentworth, Crustal studies in central California using an 800-channel seismic reflection recording system, in Reflection Seismology: A Global Perspective, Geodyn.Ser., vol. 13, edited by M. Barazangi and L. Brown, pp. 183-196, AGU, Washington, D. C. 1986.

Zoback, M. D., et at., New evidence on the state of stress of the San Andreas fault system, Science, 238, 1105-1111, 1987.

C. M. Wentworth, U. S. Geological Survey, 345 Middlefield Road, Menlo Park, CA 94025. M. D. Zoback, Department of Geophysics, Stanford University, Stanford, CA 94305.

(Received July 12, 1988;

revised August 26, 1988;

accepted October 28, 1988.) 